\title{
EJEM \\ Econ.J.Emerg.Mark.

\section{Unit root tests in the presence of structural breaks: Evidence from African stock markets}

\author{
Osarumwense Osabuohien-Irabor
}

Department of International Economics, School of Economics and Management, Ural Federal University, Yekaterinburg, Sverdlovsk Oblast, Russia.

Corresponding author: oosabuokhien-irabor@urfu.ru

\begin{tabular}{|c|c|}
\hline Article Info & Abstract \\
\hline $\begin{array}{l}\text { Article history: } \\
\text { Received : } 10 \text { August } 2020 \\
\text { Accepted : } 16 \text { September } 2020 \\
\text { Published : } 25 \text { October } 2020 \\
\end{array}$ & $\begin{array}{l}\text { This paper examines whether stock prices for fourteen African countries } \\
\text { are affected by transitory or permanent shocks. This study answers } \\
\text { whether Africa stock market indices are mean-reverting or random-walk } \\
\text { in the presence of multiple structural breaks. To investigate African }\end{array}$ \\
\hline $\begin{array}{l}\text { Keyrwords: } \\
\text { African stocks, structural breaks, } \\
\text { mean-reversion, random-walk, unit } \\
\text { root test }\end{array}$ & $\begin{array}{l}\text { determined structural break tests of Zivot and Andrews (1992) and } \\
\text { Lumsdaine and Papell (1997), respectively. Findings/Originality: Our } \\
\text { results show that almost all African equity price indices follow the }\end{array}$ \\
\hline $\begin{array}{l}\text { JEL Classification Code: } \\
\mathrm{C} 1, \mathrm{C} 22, \mathrm{C} 23, \mathrm{~N} 2\end{array}$ & $\begin{array}{l}\text { mean-reversion properties in its equity prices. It implies that investors in } \\
\text { African stock markets cannot rely on past information and behavior to } \\
\text { predict stock market movements or develop their trading strategies. The }\end{array}$ \\
\hline DOI: $10.20885 /$ jem.vol12.iss2.art1 & $\begin{array}{l}\text { result also confirms that the Augmented Dickey-Fuller (ADF) unit root } \\
\text { test is not applicable in the presence of structural breaks in African stock } \\
\text { markets. }\end{array}$ \\
\hline
\end{tabular}

\section{Introduction}

There has been intense debate among financial economists and practitioners on whether stock prices follow random-walk (unit roots) or mean-reversion (trend stationary) processes. If stock price is a mean revert, then there is a tendency for prices to return to its trend path after a period of time. This certainly enables investors to forecast future returns by using information on past returns. However, random walk process has two main properties. This includes long and short-memory processes. For the long-memory processes, the shocks to prices are highly persistent, and the first differentiation of the price series yields white-noise. Short-memory processes are independently and identically distributed prices. Furthermore, if stock price with a random-walk process experiences any shock there is the tendency that the price level cannot return to a trend path over time and this can become permanent (Chaudhuri \& Wu, 2003). When this happens, predicting stock returns based on historical observation becomes unfeasible. The presence of unit roots also indicates the continuous increase in stock price volatility in the long run. Fama and French (1988) and Poterba and Summers (1988) were the first to document the existence of mean reversion in US stock prices. The absence of unit roots in stock price series implies a mean reversion of stock prices. This makes stock price movement predictable using past available information. There are numerous unit root tests for verifying the order of integration of time series data, these include; Dickey and Fuller (1979) - ADF test; Phillips and Perron (1988) - Phillips-Perron test, Kwiatkowski, Phillips, Schmidt, and Shin (1992) - KPSS test, Elliott, Rothenberg, and Stock (1996), and Ng and Perron (1995, 2001) - NGP test, etc. However, several studies, particularly Perron (1989), have shown that structural breaks impact unit root test to be biased towards non-rejection of the null hypothesis. 
A stationary series is said to have a mean and covariance that does not vary over time. This indicates that such series is mean-reverting and any possible shock to the series will create a temporary effect. Unfortunately, most standard unit root tests will report bias and non-reliable results of non-rejection of the unit root for such series. For this reason, avalanche of research literatures on unit root tests and structural breaks have emerged. Although with mix results, but majority of the literature has suggested that with the inclusion of structural breaks, rejection of the null hypothesis of unit roots may not be possible (Zivot \& Andrews, 1992) - reject the null at the $10 \%$ level; Narayan \& Popp (2010) - reject the null at the 1\% level; Fourier ADF test of Enders and Lee (2012) - cannot reject the null; One break LM test of Lee and Strazicich (2013) - cannot reject the null; Two break LM test of Lee and Strazicich (2003) - cannot reject the null; Fourier LM test of Enders and Lee (2012) - cannot reject the null). In other words, the presence of structural breaks impacts the unit root tests. But sadly, most empiricists of African financial markets have continued to rely only on either the ADF or the PP tests which is biased in the presence of structural breaks, to determine the stationarity of a dynamics process. To this end, we investigate whether African stock markets indices contain unit root (random walks) or stationarity (meanreverting) in the presence of unknown structural break (i.e whether the time series are affected by transitory or permanent shocks). And whether the use of ADF and PP tests in African financial markets empirical analysis is appropriate.

The increasing awareness and investments from different investors in stock markets across the globe has serves as the main reason why researchers have continued to probe into the performances of world equity markets with no exception to any continent. Is A frican stock markets random-walk or mean reverting in the presence of multiple breaks? Knowledge of African stock prices behavior would in no doubt help markets investors predict market behavior. Before 1989, the Africa continent could only boast of five stock markets in the sub-Saharan region and three stock markets in the Northern region. And at the end of 2003, a total of twelve formal stock markets were in Africa and monitored by S\&P Emerging Markets Database (EMDB). By the year 2012, the numbers of stock exchange increased to twenty-nine representing thirty-eight nation's capital markets (Moin, 2007). African stock market investors are filled with doubt and uncertainty about market conditions due to the high level of risk associated with African stock markets. Some of these risks include political instability, currency fluctuation, terrorism, etc. For many years Africa countries, particularly northern African countries have been plagued with numerous social vice which has cause high volatility on the stock market prices. Senbet and Otchere (2008) document that currency depreciation causes negative performance on African stock markets. As at 2019, and based on market liquidity, five Africa's largest stock exchange includes Johannesburg Stock Exchange (JSE), Nigerian Stock Exchange (NSE), Egyptian Stock Exchange, Casablanca Stock Exchange, and Namibian Stock Exchange.

The rest of this paper is organized as follows. The next section reviews the relevant literature related to our study and hypothesis development of this paper. The following section shows the methodology, preliminary analysis, and the data applied in our analysis. This includes testing for the presence or absence of unit root using two different unit root tests. The last two sections report the results of our empirical analysis as well as the study robustness check and summarize the research based on the empirical results as well as the significance of the study. Results from both Ben-David, Lumsdaine, and Papell (2003) and Zivot and Andrews (1992) reveals that almost all African stock market prices movement are random walk. However, this is different for the Senegal stock exchange market. The analysis will provide a broad knowledge of African stock market behavior to both the real investors and potential investors.

Much empirical literature has emerged to test whether a particular stock market can be classified as a random-walk or a mean-reverting process. However, the results from these empirical analyses from different financial markets and other time series data have been mixed. While some 
literature finds evidence of unit root (random walk), other literature simply shows mean reverting process (absence of unit root). For instance, Narayan, Liu, and Westerlund (2016), Tiwari and Kyophilavong (2014), Tuyon and Ahmad (2016), and Urquhart and McGroarty (2016), etc report results of their empirical analysis of stock markets as a mean-reverting process. However, other literature finds evidence of random-walk in their empirical studies. These literature include Dewandaru, Masih, and Masih (2016), Graham, Peltomäki, and Sturludóttir (2015), Hiremath and Narayan (2016), Sensoy and Tabak (2015).

However, most studies on random-walk and mean-reversion are on emerged markets with a handful of researches on African stock markets. Smith, Jefferis, and Ryoo (2002) categorized eight African stock markets like South Africa, medium-sized markets, small new markets with growth, and small new market yet to take off. They investigate these African markets whether it is random-walks or mean reverting using the multiple variance ratio test of Chow and Denning (1993). Their results show that the South African market stock price index follows a random walk, while the hypothesis is rejected in the remaining seven others (Egypt, Kenya, Morocco, Nigeria, Zimbabwe, Botswana, and Mauritius) due to autocorrelation of returns. Lawal, Somoye, and Babajide (2017) employed both the wavelet and time domain unit root tests to investigate the random-walk validity hypothesis for seven African stock markets. With the frequency domain factor, their results reject the null hypothesis of unit roots for all seven African stock markets studied. This indicates that African stock markets (Cote D' Ivoire, Egypt, Kenya, Morocco, Nigeria, South Africa, and Zimbabwe) are mean reverting using the frequency domain. Morris, Van Vuuren, and Styger (2009), test the South African All Share Index (ALSI 40) data using the Wavelet and Markov Switching framework. While the Wavelet analysis indicates that most share prices and the share index are mean-reverting over the long run, the Markov frame walk shows the presence of patterns in the historic time series, providing additional support for the mean-reverting processes. Magnusson and Wydick (2002) examine and compare eight largest African stock markets with emerging stock markets in South-east Asia and Latin America, whether they are mean-reverting or random-walks. Their findings indicate random-walk processes in African. Chia, Jiun, and Xin (2019) investigate the mean reversion of African stock market indices for Egypt, South Africa, Kenya, Mauritius, Morocco, Nigeria, and Tunisia using the ADF, GD-GLS, PP as well as the panel unit root tests. The panel unit root test was shown to reject the unit root null hypothesis, which shows evidence of mean reversion in the markets.

Numerous literature has applied and examined the unit root hypothesis in different African financial markets activities. Gyamfi, Kyei, and Gill (2016), examined the stationarity of eight African stock markets indices. They applied the non-linear ADF unit root test and the modified Wald type test using the ESTAR framework. Their results show that both tests failed to reject the null hypothesis of unit roots in all markets except for Botswana. Abakah, Alagidede, Mensah, and Ohene-Asare (2018) use the Non-Linear Fourier unit root test with allows for breaks to test the Random Walk Hypothesis (RWH) for five African stock markets (South Africa, Nigeria, Egypt, Ghana, and Mauritius). The non-linear fourier unit root test did not reject the random walks hypothesis for South Africa, Nigeria, and Egypt, while Ghana and Mauritius show weak-form inefficiency. Anoruo and Gil-Alana (2011) investigate stock market behavior for several African countries using the fractionally integrated techniques which account for structural breaks in the data. Their empirical analysis report evidence for random walks in all the stock markets examined. To the best of our knowledge, not much has been done in testing whether African stock market indices are mean-reverting or random walks in the presence of multiple structural breaks. Therefore, this study tends to bridge the research gap, by investigating fourteen major African stock markets indices whether the market indices are random-walks or mean-reverting, taking into consideration the occurrence of multiple breaks. 
Avalanche of literature has focused on testing the unit root hypothesis, but very few studies exist with regards to unit roots and structural change. Glynn and Perera (2007) study examined the unit roots hypothesis in the presence of structural breaks using different data. Their study reviewed some previous empirical studies based on Nelson and Plosser (1982) data and other studies. They concluded that there is no consensus on the most appropriate method in testing unit root hypothesis. Ling, Nor, Saud, and Ahmad (2013) investigated unit root hypothesis and structural breaks in macroeconomics data of ASEAN countries. They applied the one and two breaks models of Ben-David et al. (2003) and Zivot and Andrews (1992) models. Their result shows that, in the ZA model, the US Dollar terms denomination series follows the trend-stationary processes, whereas using the LP models, the series under local currency terms appears to reject the null hypothesis of a unit root. Lee and Strazicich (2003), propose LM unit root test which determines a structural break in intercept and trend. They compared the power and size properties of their model to one-break unit root test of Zivot and Andrews (1992). Their model one-break LM unit root test shows no size distortions in the presence of structural break under the null compares to Zivot and Andrews (1992). Hayashi (2005) examined structural changes in Japanese major macroeconomic time series using the Yamamoto's (1996) augmented stepwise Chow test to determine the stationarity of the series using unit root tests. Structural breaks were found for all the time series except the Yen/Dollar exchange. Suresh and Shylajan (2015) paper investigated the presence of structural changes in Indian's GDP, GNP, and other components. They used the Narayan \& Popp (2010) two breaks structural models in their empirical analysis. Their results showed that the 1990's reforms affected the growth of GNP, GDP, and sectors such as trade, finance, and public administration. However, the agriculture and manufacturing sectors were unaffected.

\section{Methods}

We apply the natural logarithm of stock market indices for the fourteen selected African stock markets. These include Nigeria (NGSE), South Africa (FTSE South Africa), Kenyan (NASI), Tanzania (DSEI), Namibia (FTSE NSX Overall), Uganda (ALSIGU), Mauritius (SEMDEX), Egypt (EGX30), Morocco (MASI), Botswana (BSE FRS), Cote D' (BRVM Composite), Zambia (LASILZ), Tunisia (TUNIDEX), and Senegal (TTLS). We use the cumulated weekly five daily data from Monday to Friday, for the period May 31, 2009 to April 19, 2020. However, Namibia (FTSE NSX Overall); Cote D' (BRVM Composite), and Senegal (TTLS) have different data ranges, which are; May 5, 2010 to April 19, 2020; January 23, 2011 to April 19, 2020; and February 22, 2015 to April 19, 2020 respectively. The time period for some African countries is different, depending on the geographical location (e.g. West African, East African, North African, and South African) of the countries. Our data range allows for the possibility of structural changes. It was retrieved from Bloomberg data services.

\section{Unit Root Tests and Structural Break}

Before now, the traditional view of unit root hypothesis was that the present shocks to a dynamic process only have a momentary effect and fades during the long-run movement (or the series remain unaltered by the shock during the long-run movement). However, the seminal paper of Nelson and Plosser (1982), renewed the interest in the debate on the unit root hypothesis. They posited that random shocks to financial (dynamics) series are not temporary but have permanent effects in the long run. This indicates that the fluctuations are simply not transitory. However, these results were not accepted by Perron (1989), who argued that ADF tests are usually biased towards the non-rejection of the null hypothesis in the presence of a structural break. Our major objective in this study is to test whether African stock market indices are random-walk or mean reverting 
processes. i.e if shocks to Africa stock series are simply transitory or remained permanent. We consider the null hypothesis that $y_{t}$ contains unit root process, as shown in equation (2), hence we take the natural logarithm of the stock-price index at time $t$.

$$
\begin{aligned}
& \Delta y_{t}=\alpha y_{t-1}+\varepsilon_{t} \\
& \Delta y_{t}=\mu+\alpha y_{t-1}+\varepsilon_{t} \\
& \Delta y_{t}=\mu+\beta_{t}+\alpha y_{t-1}+\varepsilon_{t}
\end{aligned}
$$

We further examine the time series properties of our data without allowing structural breaks by performing the Augmented Dickey-Fuller (ADF) Dickey and Fuller (1979) and Phillips-Perron (1988) tests procedures. We also perform the Modified Akaike Information Criterion (MAIC) propose by $\mathrm{Ng}$ and Perron (2001) to choose the optimal lag in the ADF regression. The use of appropriate lags augments the ADF regression to ensure the errors are white noise and serial correlation free. The ADF adds lagged differences to these models, thus;

$$
\begin{aligned}
& \Delta y_{t}=\alpha y_{t-1}+\sum_{i=1}^{k} c_{i} \Delta y_{t-i}+\varepsilon_{t} \\
& \Delta y_{t}=\mu+\alpha y_{t-1}+\sum_{i=1}^{k} c_{i} \Delta y_{t-i}+\varepsilon_{t} \\
& \Delta y_{t}=\mu+\beta_{t}+\alpha y_{t-1}+\sum_{i=1}^{k} c \Delta y_{t-i}+\varepsilon_{t}
\end{aligned}
$$

Where;

$$
\mu \text { denotes intercept, }
$$

$y$ denotes the natural logarithms of the African stock index,

$\Delta y_{t-i}$ represents $k$ augmentations to control for potential serial correlation,

$\varepsilon_{t}$ denotes white noise residuals,

$\Delta$ denotes the first different operator

$t$ is a time trend term; $\alpha, \beta$, and $c$ are coefficient respectively

Equation (1)-(3) are the basic regression equations. Whilst Equation (1) shows a regression equation with no constant and trend, Equation (2) contains constant but no trend. Equation (3) regression contains both constant and trend. Equation (5) tests for the null hypothesis of a randomwalk against a mean stationary alternative, while Equation (6) tests for the same null against a trend stationary alternative. If the estimate of $\alpha$ coefficient is not significantly different from zero, the null hypothesis of a unit root (random walk) cannot be rejected. However, if $\alpha<0$ the alternative hypothesis of a mean reversion processes holds. According to Chaudhuri and Wu (2003), the Phillips-Perron (1988) tests work in a similar way not different from the ADF test, except the extra regressors, $\Delta y_{t-i}$ which are not added in the regression equation. But the serial correlation of the residuals is corrected through a non-parametric approach.

One major weakness researchers have identified in ADF and PP tests is that they do not allow for the possibility of a structural break and they possess low power against slow meanreverting alternatives processes in small samples. Therefore, not rejecting the null hypothesis, does not connote evidence against a mean-reverting process. For this reason, Perron (1989) argued that unit root tests can erroneously reject the null hypothesis if the structural breaks are ignored. This means that these tests will certainly perform poorly if there is a break in the deterministic trend. In the spirit of Perron (1989) criticism, Zivot and Andrews (1992), (hereafter referred to as, ZA) developed a unit root test that endogenously searches for one most significant structural break point around a broken trend. Model $\mathrm{C}$ in the ZA test allows for a structural break in both the intercept and slope. The ZA unit root test is a sequential test that uses the full sample and a dummy variable. The break date is the date that corresponds to the minimum t-statistics. However, the Ben-David et al. (2003) (hereafter referred to as, LP) unit root test suggested by Ben-David et al. 
(2003) questioned the ability and efficiency of a unit root test that accounts for a single break. Hence, they extend the ZA test by introducing a new unit root procedure that accounts for the two most significant structural breaks by adding two endogenous breaks in equation (6) as an extension of model C to model CC. The ZA and LP model is given respectively as;

$\Delta y_{t}=\mu+\beta_{t}+\alpha y_{t-1}+\theta D U_{t}+\gamma D T_{t}+\sum_{i=1}^{k} c \Delta y_{t-i}+\varepsilon_{t}$

Where;

TB denotes the time of break

$D U_{t}=1$ if $t>T B$ otherwise zero

$D T_{t}=t-T B$ if $t>T B$ otherwise zero

The "trimming region" for $T B$ covers $0.15 T-0.85 T$ period.

For the LP unit root test,

$\Delta y_{t}=\mu+\beta_{t}+\alpha y_{t-1}+\theta D U 1_{t}+\gamma D T 1_{t}+\theta D U 2_{t}+\gamma D T 2_{t}+\sum_{i=1}^{k} c \Delta y_{t-i}+\varepsilon_{t}$

Where;

TB denotes the time of break

$D U 1=1$ if $t>T B 1$ otherwise zero; $D U 2=1$ if $t>T B 2$ otherwise zero

$D T 1=t-T B 1$ if $t>T B$ otherwise zero; DT2 $=t-T B 2$ if $t>T B$ otherwise zero

The $D U 1_{t}$ and $D U 2_{t}$ dummy variables indicate structural breaks at $T B 1$ and $T B 2$ intercepts respectively. Similarly, the dummy variables $D T 1_{t}$ and $D T 2_{t}$ are indicators for structural breaks points in trend $T B 1$ and $T B 2$. We apply the MAIC information criterion to choose the optimal lag length and use the ZA and LP unit root tests to select the breaks points. All methodologies are based on the univariate unit roots and structural breaks.

\section{Results and Discussion}

Table 1 presents the descriptive statistics for all African stock markets. Senegal stock return (TTLS) has the lowest mean returns of -0.973 while the highest mean returns is Kenyan (NASI) with +0.139 . Amongst the variables examined, Tunisia (TUNIDEX); Morocco (MASI); Mauritius (SEMDEX) stock returns tend to be very close to the mean values, while Senegal (TTLS) returns indicates that the values are spread out over a large range of values. This is revealed by the standard deviation shown in Table 1 and the values of the interquartile ranges. The stock returns for African stock markets have distribution with fatter tails than a normal distribution, and the skewness varies among different stock markets. For instance, Namibia (FTSE NSX Overall), Botswana (BSE FRS), Cote d'Ivoire (BRVM Composite), and Zambia (LASILZ) is positively skewed, an indication that to the right tail of the distribution is longer than the left. However, this is reversed for other stock returns.

Figure 1 shows the weekly logarithm plots of African stock price indices. The time series plots show a non-stationary behavior with structural changes in the market indices. These large fluctuations vary over time with different patterns for different stock market indices. For example, a visual plot inspection of Nigeria, Namibia, Mauritius, Morocco, Cote d'Ivoire, Egypt, Botswana, and Zambia appear to have a mean reverting process that tends to drift towards its mean. But the variance appears not growing proportionally to the time interval. However, South Africa, Kenya, Tanzania, Uganda, Tunisia, Senegal shows a random walk process. The series plotted in Figure 1, shows structural breaks at the level and does not revert around the mean. Another feature observed in all the plots is the existence of multiple trend breaks where both processes whether meanreverting or random walks appear to be a non-deterministic process. This is seen in Figure 2, which 
shows the plots of market returns and in Table 2, Panel A which shows the non-significance of the unit root tests.

Table 1. African stock market prices summary statistics

\begin{tabular}{llcrrrrrrrr}
\hline \multicolumn{1}{c}{ Company } & Mean & SD & P25 & P75 & Min & Max & $\begin{array}{c}\text { Excess } \\
\text { Kurtosis }\end{array}$ & Skewness & IQR & Obs \\
\hline Nigeria & -0.038 & 2.908 & -1.399 & 1.356 & -14.492 & 15.615 & 05.694 & -0.235 & -2.755 & 569 \\
South Africa & 0.123 & 2.382 & -1.187 & 1.505 & -15.547 & 08.645 & 06.359 & -0.924 & -2.692 & 569 \\
Kenyan & 0.139 & 2.243 & -0.927 & 1.392 & -15.564 & 09.826 & 05.782 & -0.711 & -2.319 & 569 \\
Tanzania & 0.066 & 2.523 & -0.400 & 0.747 & -29.273 & 28.055 & 58.786 & -0.424 & -1.147 & 569 \\
Namibia & 0.044 & 3.987 & -1.735 & 1.606 & -41.872 & 46.098 & 60.436 & 0.380 & -3.341 & 503 \\
Uganda & 0.107 & 2.742 & -1.230 & 1.544 & -13.481 & 11.904 & 03.295 & -0.315 & -2.774 & 569 \\
Mauritius & 0.032 & 1.548 & -0.531 & 0.604 & -18.230 & 14.898 & 50.766 & -1.632 & -1.135 & 569 \\
Egypt & 0.085 & 3.997 & -1.631 & 2.321 & -26.392 & 19.319 & 06.572 & -0.649 & -3.952 & 569 \\
Morocco & -0.039 & 1.541 & -0.811 & 0.786 & -09.093 & 07.673 & 05.490 & -0.413 & -1.597 & 569 \\
Botswana & 0.071 & 2.384 & -0.005 & 0.017 & -36.810 & 36.540 & 200.88 & 0.506 & -0.022 & 569 \\
Cote D' & -0.040 & 1.658 & -1.088 & 0.866 & -05.446 & 09.137 & 03.584 & 0.821 & -1.954 & 483 \\
Zambia & 0.080 & 1.876 & -0.493 & 0.567 & -09.301 & 12.053 & 09.373 & 0.678 & -1.06 & 569 \\
Tunisia & 0.105 & 1.503 & -0.482 & 0.794 & -13.625 & 07.634 & 18.861 & -1.938 & -1.276 & 569 \\
Senegal & -0.973 & 15.11 & -2.985 & 1.904 & -228.96 & 36.131 & 194.90 & -12.78 & -4.889 & 270 \\
\hline
\end{tabular}

In Figure 2, a visual plots inspection of Mauritius, Botswana, Senegal, and Namibia show less volatility of stock price indices compare to the other stock indices. Although there was a heavy bust during the beginning of 2013, Botswana's BSE FRS appears to have the calmest index among the African stock indices in this study, and closely followed by Senegal's TTLS. Conversely, Uganda, Cote d'Ivoire, and Egypt appear to have the most volatile indices.
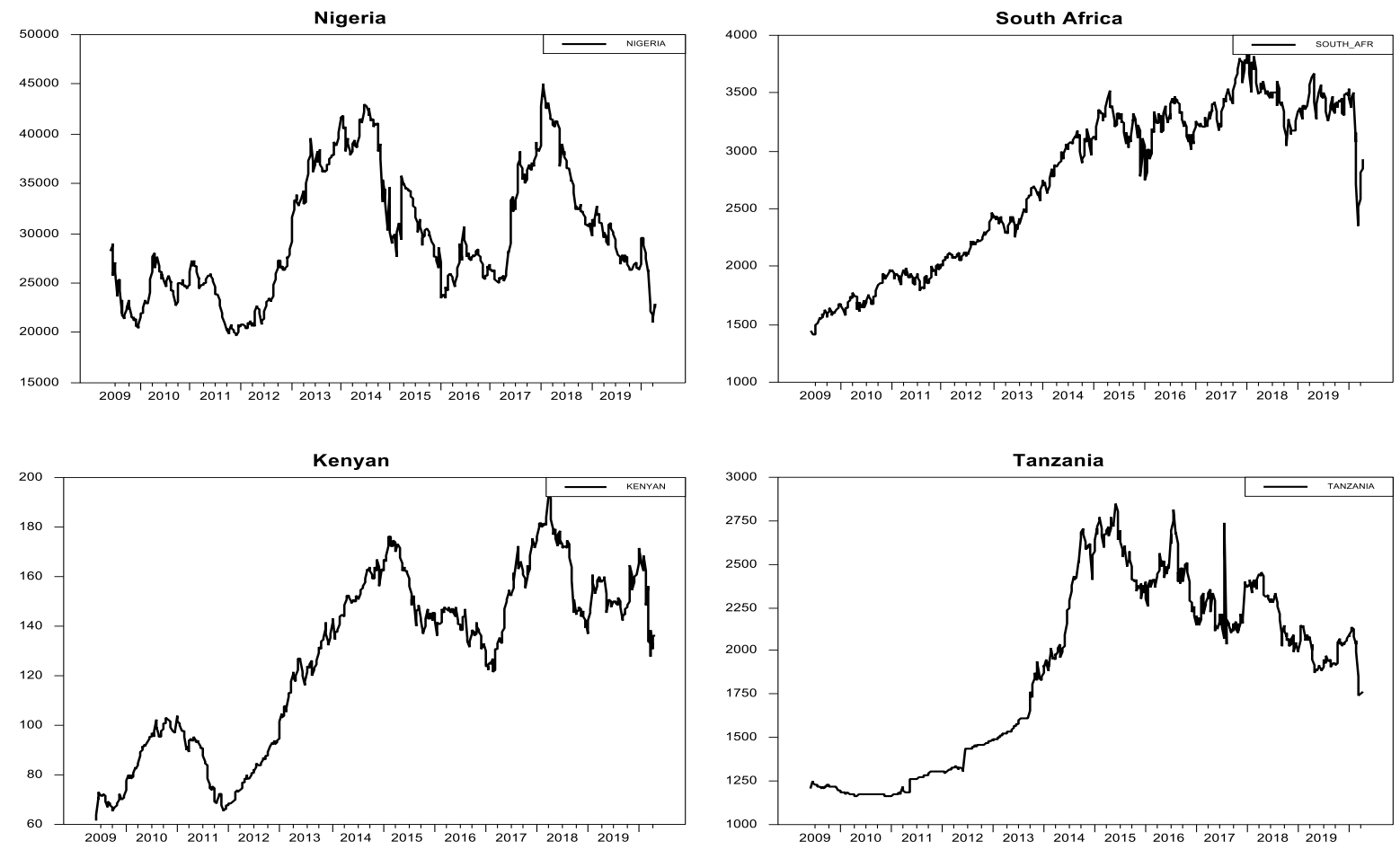

Figure 1b. The weekly log time series plot of 14 African stock market indices 

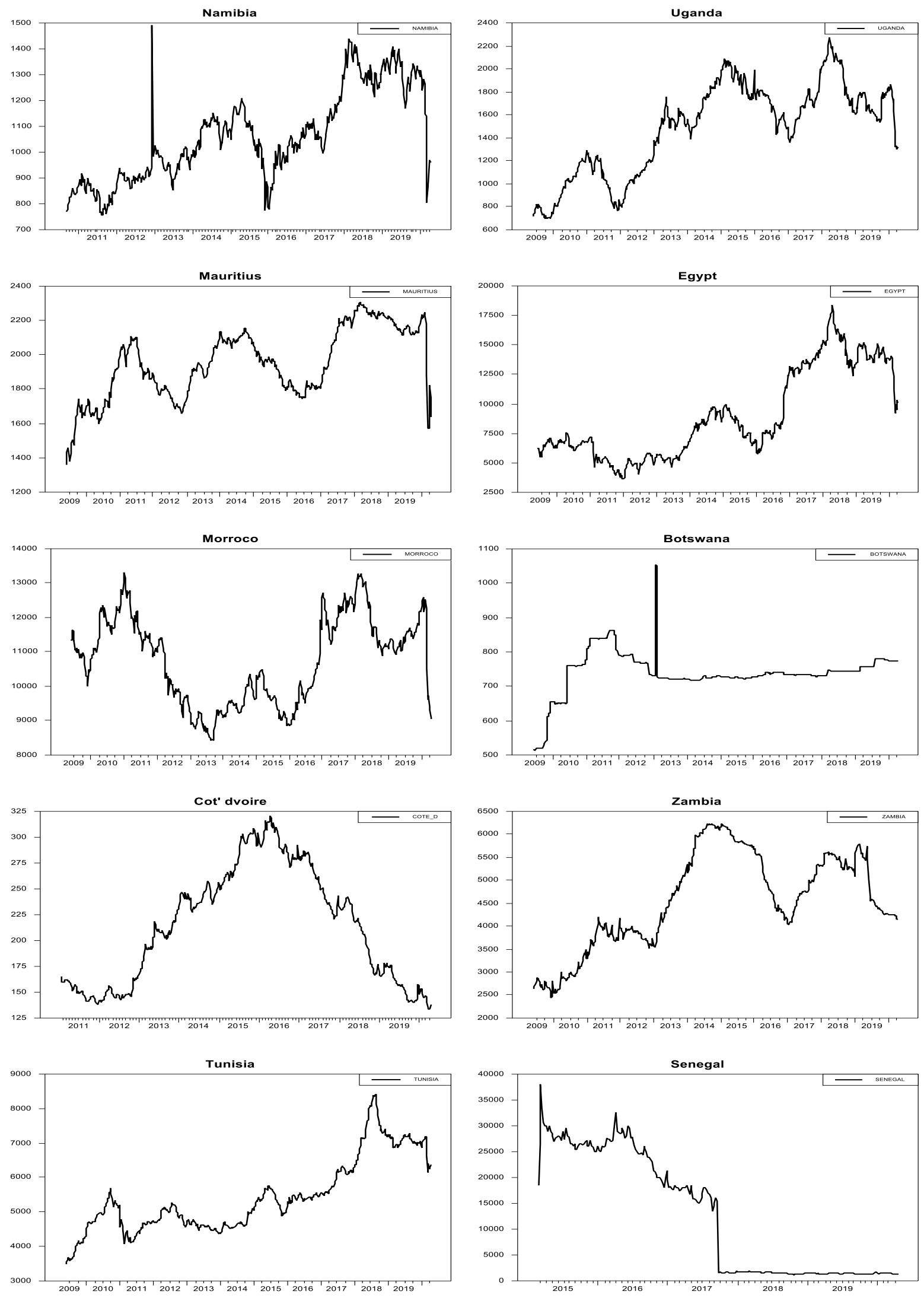

Figure 1b. The weekly log time series plot of 14 African stock market indices 
While Table 2 panel A report tests log price indices, panel B shows the results of the unit roots test for change in log prices of African stock indices. With poor power ability of ADF and $\mathrm{PP}$ tests in the presence of structural changes, results in Table 2 Panel A reveal that almost all African stocks indices, except for Botswana contain unit root. Nevertheless, Table 2, panel B shows that these series can be stationary in mean if a change in log prices is applied. Numerous scientific research papers have shown that the ADF and PP tests for unit roots cannot be relied on in the presence of structural breaks.

Table 2. ADF and PP tests for Africa stock markets indices

\begin{tabular}{|c|c|c|c|c|c|c|c|}
\hline \multirow[b]{2}{*}{$\frac{\text { Panel A }=\operatorname{In} P}{\text { Variables }}$} & \multicolumn{3}{|c|}{ ADF Test } & \multicolumn{3}{|c|}{ PP Test } & \multirow[b]{2}{*}{ Obs } \\
\hline & Intercept & $\begin{array}{l}\text { Intercept } \\
\text { and Trend }\end{array}$ & $\mathrm{k}$ & Intercept & $\begin{array}{l}\text { Intercept } \\
\text { and Trend }\end{array}$ & $\xi$ & \\
\hline In $P_{t}^{\text {Nigeria }}=\operatorname{In} P_{t}^{1}$ & -1.839 & -1.633 & 08 & -1.814 & -1.718 & 20 & 569 \\
\hline In $P_{t}^{\text {South } A .}=\operatorname{In} P_{t}^{2}$ & -2.349 & -0.563 & 06 & -2.336 & -1.252 & 20 & 569 \\
\hline $\operatorname{In} P_{t}^{\text {Kenyan }}=\operatorname{In} P_{t}^{3}$ & -1.791 & -1.573 & 08 & -2.247 & -1.780 & 20 & 569 \\
\hline In $P_{t}^{\text {Tanzania }}=\operatorname{In} P_{t}^{4}$ & -1.309 & 0.068 & 02 & -1.419 & -0.336 & 20 & 569 \\
\hline $\operatorname{In} P_{t}^{\text {Namibia }}=\operatorname{In} P_{t}^{5}$ & -2.222 & -2.378 & 03 & $-3.067 *$ & $-3.999 *$ & 12 & 503 \\
\hline In $P_{t}^{\text {Uganda }}=\operatorname{In} P_{t}^{6}$ & -2.276 & -1.086 & 00 & -2.299 & -1.563 & 17 & 569 \\
\hline In $P_{t}^{\text {Mauritius }}=\operatorname{In} P_{t}^{7}$ & $-2.863 \%$ & -2.167 & 07 & $-3.104 *$ & -2.197 & 08 & 569 \\
\hline $\operatorname{In} P_{t}^{\text {Egypt }}=\operatorname{In} P_{t}^{8}$ & -1.199 & -1.972 & 00 & -1.228 & -2.059 & 05 & 569 \\
\hline In $P_{t}^{\text {Morroco }}=\operatorname{In} P_{t}^{9}$ & -1.822 & -1.799 & 02 & -2.017 & -1.192 & 11 & 569 \\
\hline $\operatorname{In} P_{t}^{\text {Botswana }}=\operatorname{In} P_{t}^{10}$ & $-4.203^{* *}$ & $-3.933 *$ & 06 & $-4.019 * *$ & $-3.825^{*}$ & 10 & 569 \\
\hline $\operatorname{In} P_{t}^{\text {Cot.D'}}=\operatorname{In} P_{t}^{11}$ & -0.3798 & 0.188 & 01 & -0.406 & 0.212 & 12 & 483 \\
\hline In $P_{t}^{\text {Zambia }}=\operatorname{In} P_{t}^{12}$ & -2.233 & -1.566 & 18 & -2.118 & -1.013 & 20 & 569 \\
\hline In $P_{t}^{\text {Tunisia }}=\operatorname{In} P_{t}^{13}$ & -1.937 & -2.862 & 13 & -2.111 & -2.619 & 18 & 569 \\
\hline $\begin{array}{l}\text { In } P_{t}^{\text {Senegal }}=\operatorname{In} P_{t}^{14} \\
\text { Panel B }=\Delta \operatorname{In} P\end{array}$ & -0.771 & -2.301 & 00 & -0.731 & -2.390 & 11 & 270 \\
\hline$\Delta \operatorname{In} P_{t}^{\text {Nigeria }}=\Delta \operatorname{In} P_{t}^{1}$ & $-5.363^{* *}$ & $-5.474 * *$ & 13 & $-22.424 * *$ & $-22.438^{* *}$ & 09 & 569 \\
\hline$\Delta \operatorname{In} P_{t}^{\text {South } A .}=\Delta \operatorname{In} P_{t}^{2}$ & $-24.248^{* *}$ & $-24.335^{* *}$ & 00 & $-25.244 * *$ & $-25.698^{* *}$ & 14 & 569 \\
\hline$\Delta \operatorname{In} P_{t}^{\text {Kenyan }}=\Delta \operatorname{In} P_{t}^{3}$ & $-4.244 * *$ & $-4.406^{* *}$ & 15 & $-24.130^{* *}$ & $-24.096^{* *}$ & 17 & 569 \\
\hline$\Delta \operatorname{In} P_{t}^{\text {Tanzania }}=\Delta \operatorname{In} P_{t}^{4}$ & $-3.755^{* *}$ & $-3.999 * *$ & 17 & $-32.881 * *$ & $-33.308^{* *}$ & 15 & 569 \\
\hline$\Delta \operatorname{In} P_{t}^{\text {Namibia }}=\Delta \operatorname{In} P_{t}^{5}$ & $-28.292 * *$ & $-28.305^{* *}$ & 00 & $-29.108^{* *}$ & $-29.179 * *$ & 03 & 503 \\
\hline$\Delta \operatorname{In} P_{t}^{\text {Uganda }}=\Delta \operatorname{In} P_{t}^{6}$ & $-5.525^{* *}$ & $-5.688^{* *}$ & 09 & $-23.133^{* *}$ & $-23.182^{* *}$ & 16 & 569 \\
\hline$\Delta \operatorname{In} P_{t}^{\text {Mauritius }}=\Delta \operatorname{In} P_{t}^{7}$ & $-5.728 * *$ & $-5.977 * *$ & 15 & $-18.974 * *$ & $-19.006^{* *}$ & 19 & 569 \\
\hline$\Delta \operatorname{In} P_{t}^{E g y p t}=\Delta \operatorname{In} P_{t}^{8}$ & $-22.894 * *$ & $-22.874^{* *}$ & 00 & $-22.934 * *$ & $-22.935^{* *}$ & 00 & 569 \\
\hline$\Delta \operatorname{In} P_{t}^{\text {Morroco }}=\Delta \operatorname{In} P_{t}^{9}$ & $-8.610^{* *}$ & $-8.610^{* *}$ & 04 & $-21.304^{* *}$ & $-21.312^{* *}$ & 08 & 569 \\
\hline $\begin{array}{l}\Delta \operatorname{In} P_{t}^{\text {Botswana }}=\Delta \operatorname{In} P_{t}^{10} \\
\Delta \operatorname{In} P_{t}^{\text {Cot. } D^{\prime}}=\Delta \operatorname{In} P_{t}^{11}\end{array}$ & $\begin{array}{l}-16.555^{* *} \\
-4.670^{* *}\end{array}$ & $\begin{array}{l}-16.579 * * \\
-5.222 * *\end{array}$ & $\begin{array}{l}01 \\
12\end{array}$ & $\begin{array}{l}-25.486^{* *} \\
-19.859^{* *}\end{array}$ & $\begin{array}{l}-25.709^{* *} \\
-19.740^{* *}\end{array}$ & $\begin{array}{l}10 \\
18\end{array}$ & $\begin{array}{l}569 \\
483\end{array}$ \\
\hline$\Delta \operatorname{In} P_{t}^{Z a m b i a}=\Delta \operatorname{In} P_{t}^{12}$ & $-3.928^{* *}$ & $-4.182^{* *}$ & 12 & $-25.217^{* *}$ & $-25.459 * *$ & 04 & 569 \\
\hline$\Delta \operatorname{In} P_{t}^{\text {Tunisia }}=\Delta \operatorname{In} P_{t}^{13}$ & $-4.375^{* *}$ & $-4.378^{* *}$ & 17 & $-22.919 * *$ & $-22.934 * *$ & 14 & 569 \\
\hline$\Delta \operatorname{In} P_{t}^{\text {Senegal }}=\Delta \operatorname{In} P_{t}^{14}$ & $-16.505^{* *}$ & $-16.471 * *$ & 00 & $-16.572^{* *}$ & $-16.569^{* *}$ & 01 & 270 \\
\hline
\end{tabular}

Notes: (a) Data employed covering the period May 31, 2009 to April 19, 2020.

(b) $* * *, * *$ and $*$ indicates significance at the $1 \%, 5 \%$, and $10 \%$ levels, respectively

(c) Modified Akaike Information Criterion (MAIC) propose by Ng and Perron (2001) is used criterion to choose the optimal lag length

(d) $\mathrm{K}=$ Optimal Lag, $\xi=$ Bandwidth 
To determine the order of integration, firstly, we start by performing the standard ADF and PP unit root tests with intercept, and with intercept and trend. For the ADF test, we use the modified AIC (MAIC) of Ng and Perron (2001) to select the optimal lag length, and the bandwidth which determines the lag truncation parameter is selected automatic bandwidth for the PP test. While we applied the logarithmic prices at the level, changes in the logarithm of stock prices were used to obtain stock returns as shown in Table 2, panel A and B respectively. The plots are shown in Figures 1 and 2 respectively. However, the report on Table 2 panel A, shows that the ADF and PP unit root tests failed to reject the hypothesis that the African stock markets indices are a random walk. In order words, almost all African stock indices are of 1(1) integrated series. While Namibia (FTSE NSX Overall) and Mauritius (SEMDEX) results are different for both the ADF and PP tests, the Botswana (BSE FRS) series appears to have a weak mean-reverting series. The reason for these mixed results may be due to model misspecification driven by the presence of structural breaks in the intercept and other deterministic components. Therefore, to validate Table 2 panel A results, there is the need to further apply unit root tests that allows breaks.
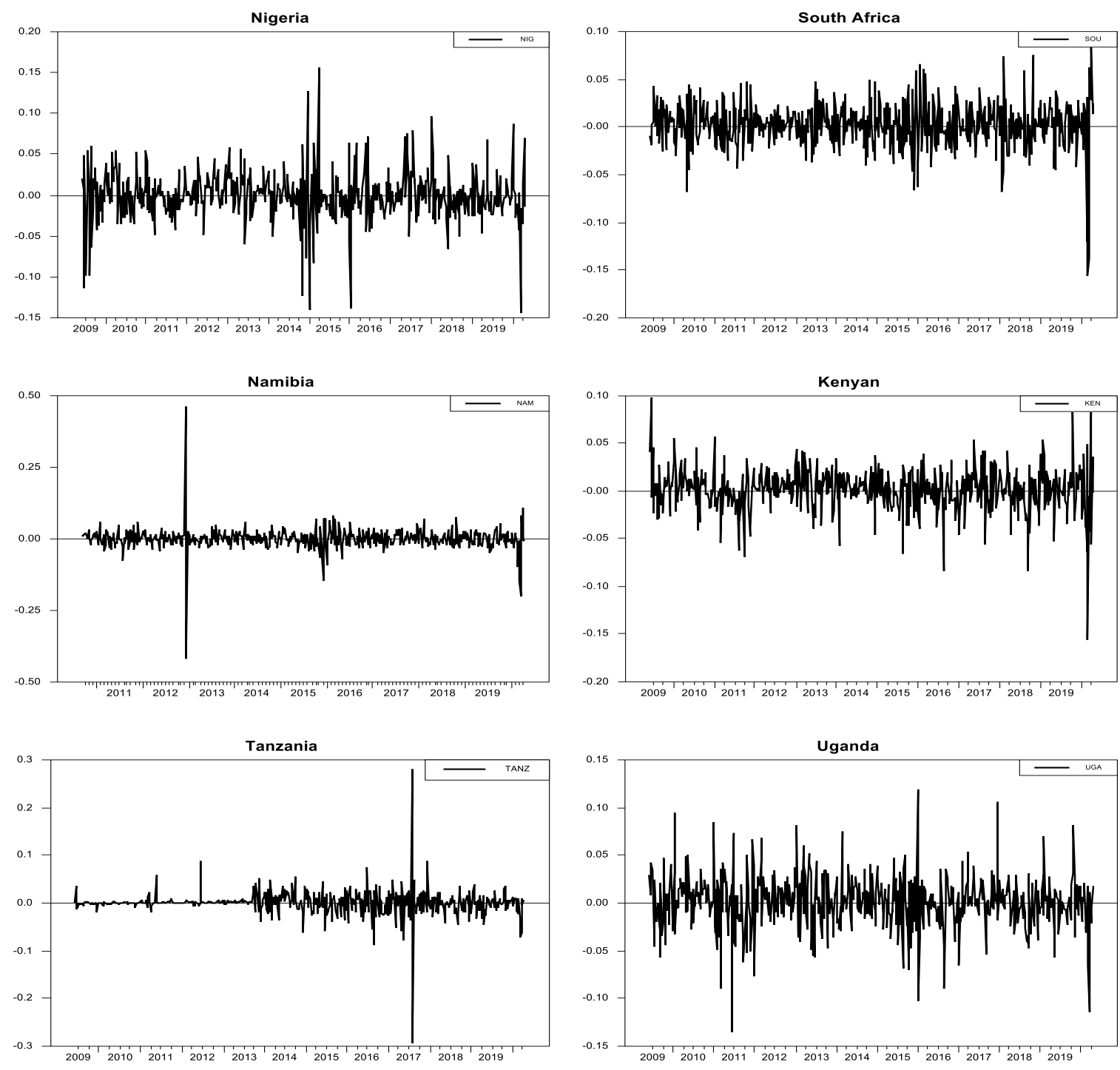

Figure 2a. Changes in weekly log time series plot of 14 African stock market indices. This is also called the returns plots 

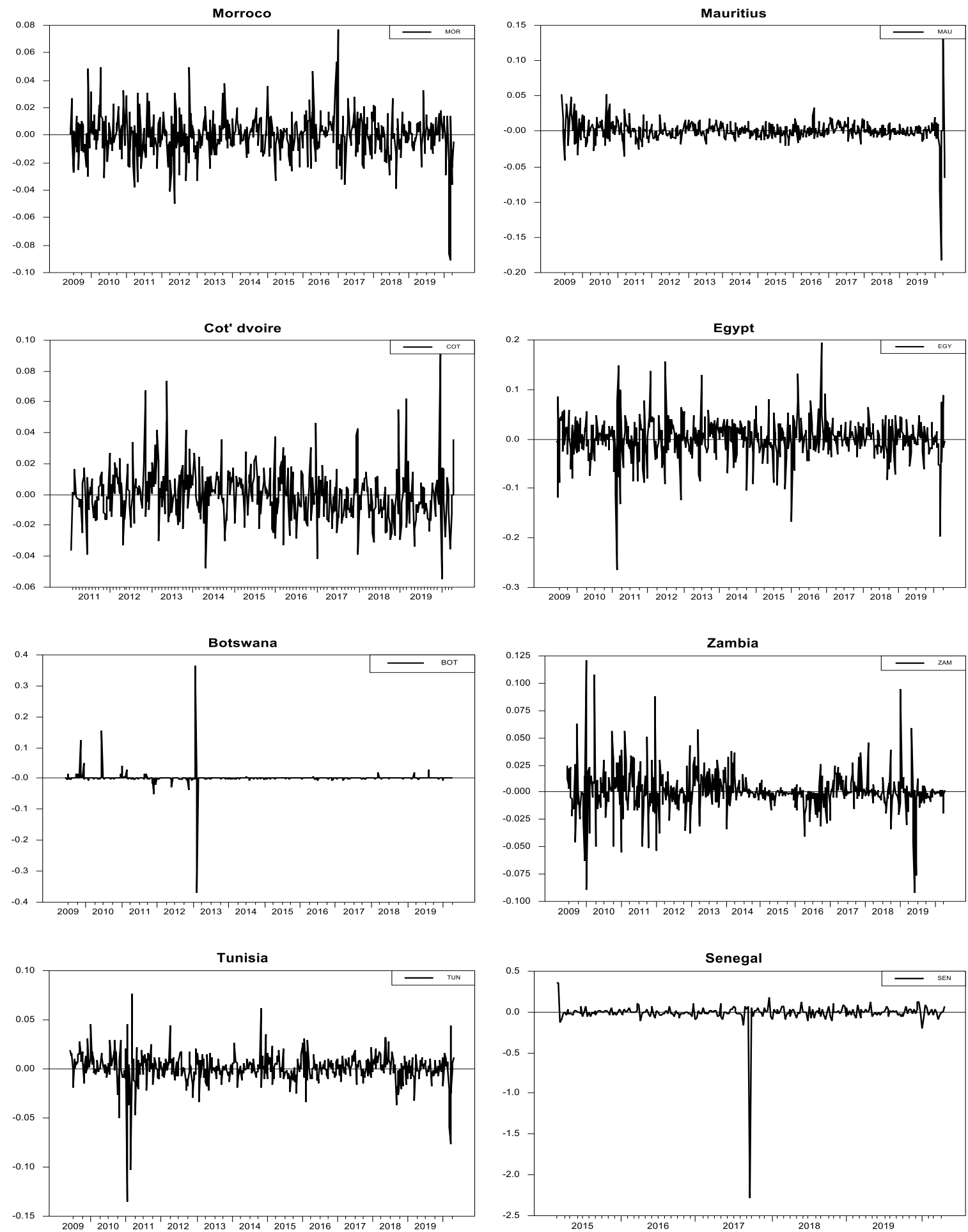

Figure 2 b. Changes in weekly log time series plot of 14 African stock market indices. This is also called the returns plots

For each African stock market indices, we estimate the model C of ZA unit root test in the presence of a structural break. and present the results in Table 3. The estimated coefficients $\mu$ and $\theta$ are statistically significant in eleven out of fourteen countries, and at least one structural break in the intercept for the sample period examined for all stock prices in the 14 African stock markets. 
In addition, the numbers of estimated coefficients of $\beta$ and $\gamma$ that are statistically significant are eight out of fourteen. This shows that eight African stock prices exhibit upward and downward trend movements. Again, there exists at least one structural break point in trend in eight countries. The coefficient for $\theta$ and $\gamma$ is significant for South Africa (FTSE South Africa); Tanzania (DSEI); Namibia (FTSE NSX Overall); Mauritius (SEMDEX); Egypt (EGX30); Tunisia (TUNIDEX); and Senegal (TTLS) suggesting that the structural change at the time of break (TB) have impacted both the intercept and the trend. Our result shows firm support for a random walk with one endogenous break as clearly seen in the BP Stat column. Except for the Senegal stock series which shows to be mean reverting. The breaking points (BP) in Table 3 are written as TB in our ZA equation and endogenously determined. The break date is the date that corresponds to the minimum t-statistics stated in Table 3 as TB stat.

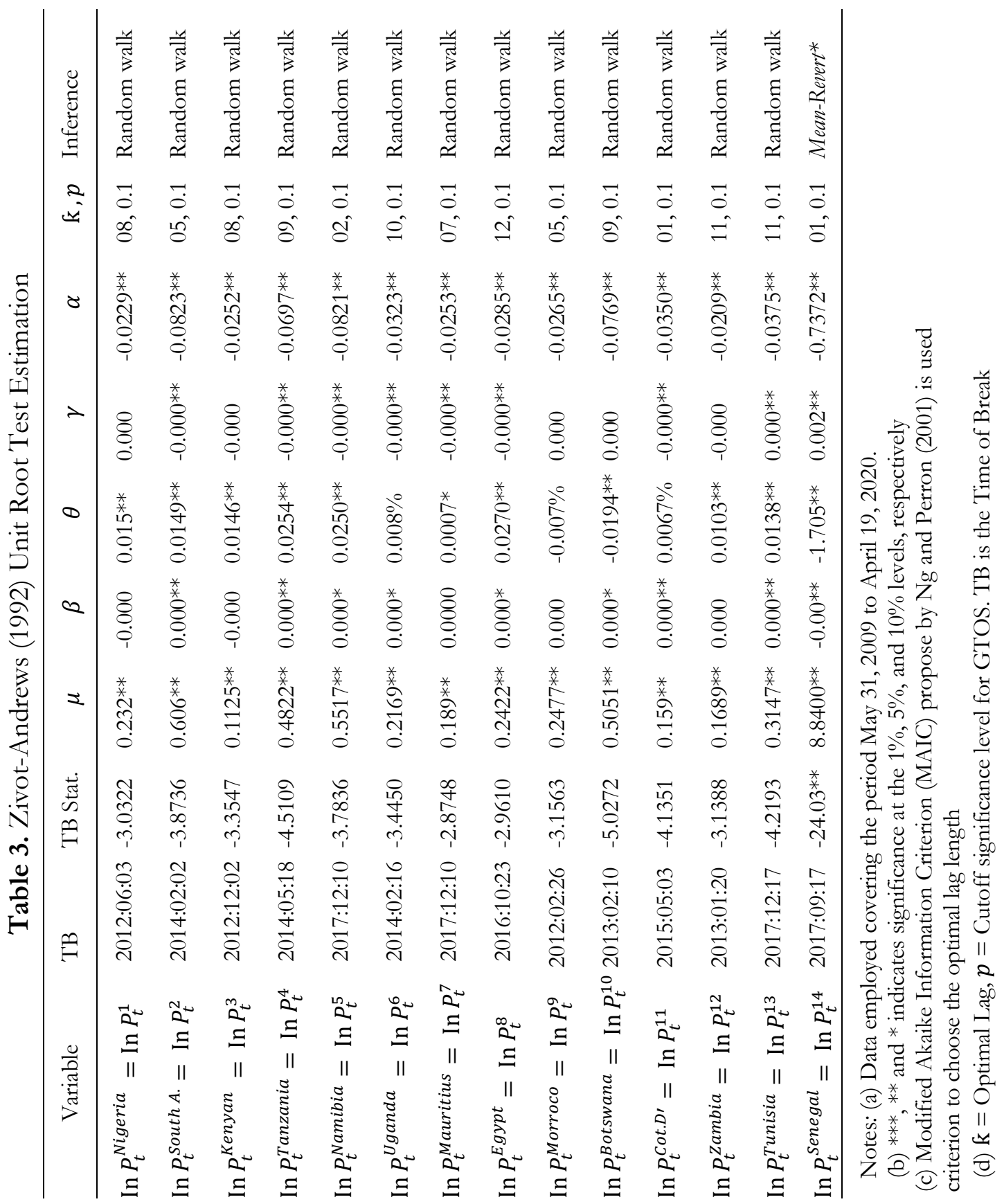


In investigating the series of a dynamics process (e.g stock indices, exchange rate, etc), many researchers have continued to 'churn out' empirical results regarding random-walk (unit roots) and mean-reversion (trend stationary) processes without putting into consideration the impact of the structural changes. Some of these researchers include; Chia et al. (2019), Magnusson and Wydick (2002), and Smith et al. (2002). They obtained mixed results in their investigation on whether African countries are affected by transitory or permanent shocks. Again, most researchers only relied on the use of ADF to conduct their empirical analysis. But the Augmented Dickey-Fuller test is known to perform poorly in the presence of structural breaks. Therefore, this paper controlled for structural breaks using two different Ben-David et al. (2003) and Zivot and Andrews (1992) endogenously determined structural break tests to analyzed two unit root tests. The empirical analysis shown in Table 5 reveals the possible events that "triggered" the sudden changes in the variances of the series. This is another notable and insightful aspect of this paper. Our results also reveal that, aside from the Ebola pandemic and Liberia civil war, most of the shock to the African stock market are external, particularly oil-related spillover effects, see Table 5. However, our results are partly similar to Gyamfi et al. (2016) study, which failed to reject the null hypothesis of unit roots in seven (Egypt, Kenya, Mauritius, Morocco, Nigeria, South Africa, Tunisia) other African stock market indices, except for Botswana. Unlike our methodology framework which accounts for structural breaks, they applied the non-linear ADF unit root test and the modified Wald type non-linear unit root test, in the ESTAR framework. Nevertheless, other studies that have also examined how structural changes influence the unit roots include Chaudhuri and Wu (2003), Glynn and Perera (2007), Hayashi (2005), Ling et al. (2013), and Suresh and Shylajan (2015).

In Table 4, we present the empirical results of the LP unit root test allowing for major two structural breaks in African stock market price indices. With two different time of breaks, our result shows that out of fourteen Africa countries' stock markets examined, twelve countries stock market price movement are a random walk. Senegal and Botswana markets stock prices are mean reverting. However, the estimated coefficients for $\theta, \gamma, \omega$, and $\psi$ tells that the structural breaks at TB1 and TB2 for almost all the African stock markets examined does not impact the intercept and trend. Although ADF and PP unit root tests in Table 2 fail to reject unit root in Senegal (TTLS) stock market, a separate analysis of ZA and LP tests which allows for structural breaks shows strongly rejected the presence of unit roots for the stock series. This confirms that the Senegal (TTLS) stock market index is mean reverting. The LP test also confirms the ADF and PP tests of the Botswana (BSE FRS) stock market index a mean-reverting series. While some of the structural breaks have the same dates, others however have different break dates. As shown in Table 5, most of the breaks occur during the US presidential election, the Ebola pandemic, and the Libya civil war. Although without the forethought of structural changes, Gyamfil, et al., (2016) results using the ESTAR framework of modified Wald type test and the non-linear ADF unit root test, are quite consistent with our results.

\section{Robustness Check}

Critiques of $\mathrm{ADF}$ and $\mathrm{PP}$ tests have shown that the test performs poorly when there are breaks in the series. Hence, the introduction of unit root tests that allows structural breaks. The ZA and LP tests are known to be more reliable than the ADF and PP unit root tests. And as explained in the previous section, results are shown in Table 2, 3, and 4 clearly reveals that Botswana (BSE FRS) and Senegal (TTLS) stock market indices are mean reverting. Unanimously, both ZA and LP tests select the Senegal (TTLS) stock market as mean-reverting. LP test confirmed the results of both the ADF and PP test in selecting Botswana (BSE FRS) stock market index as mean-reverting series. 


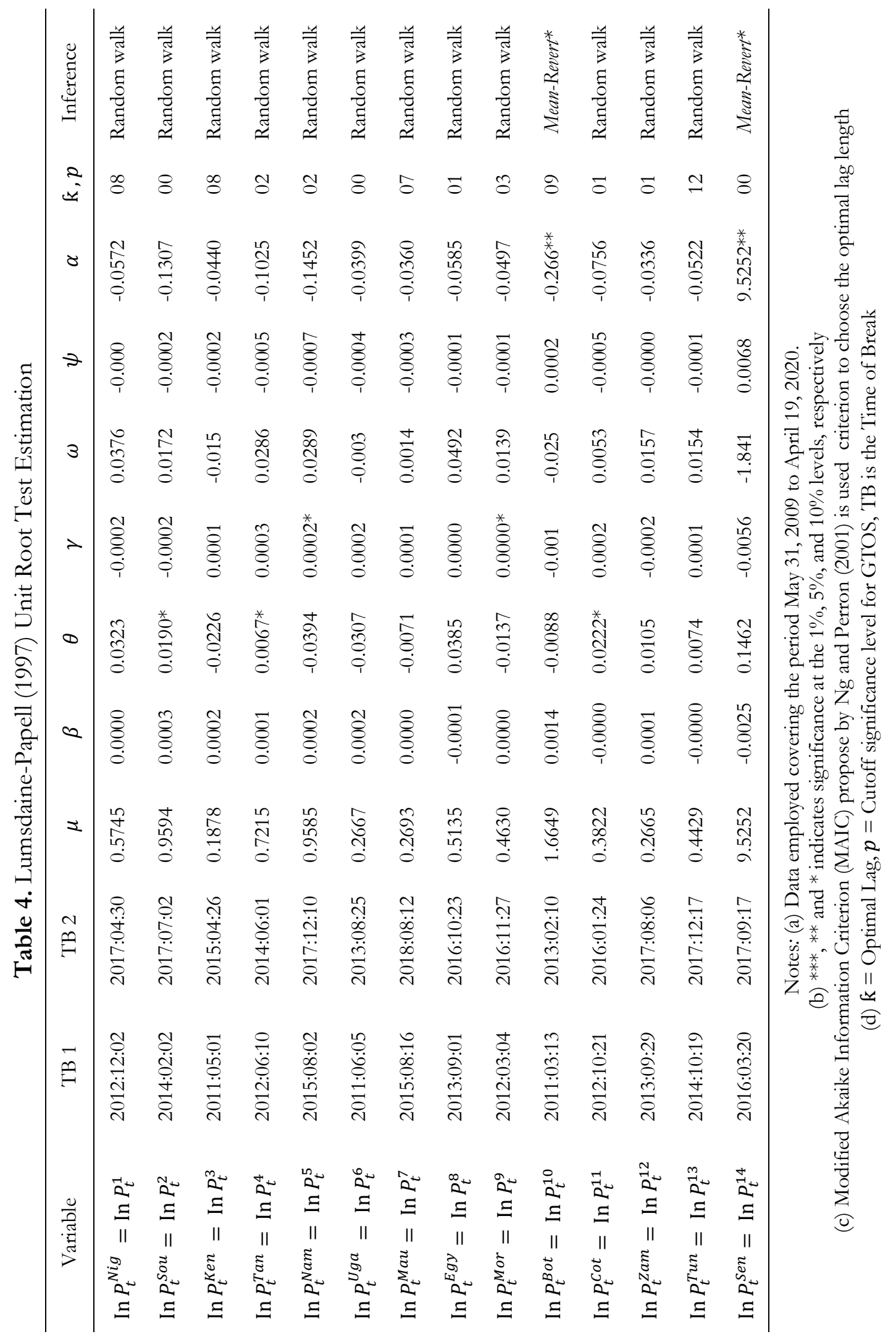




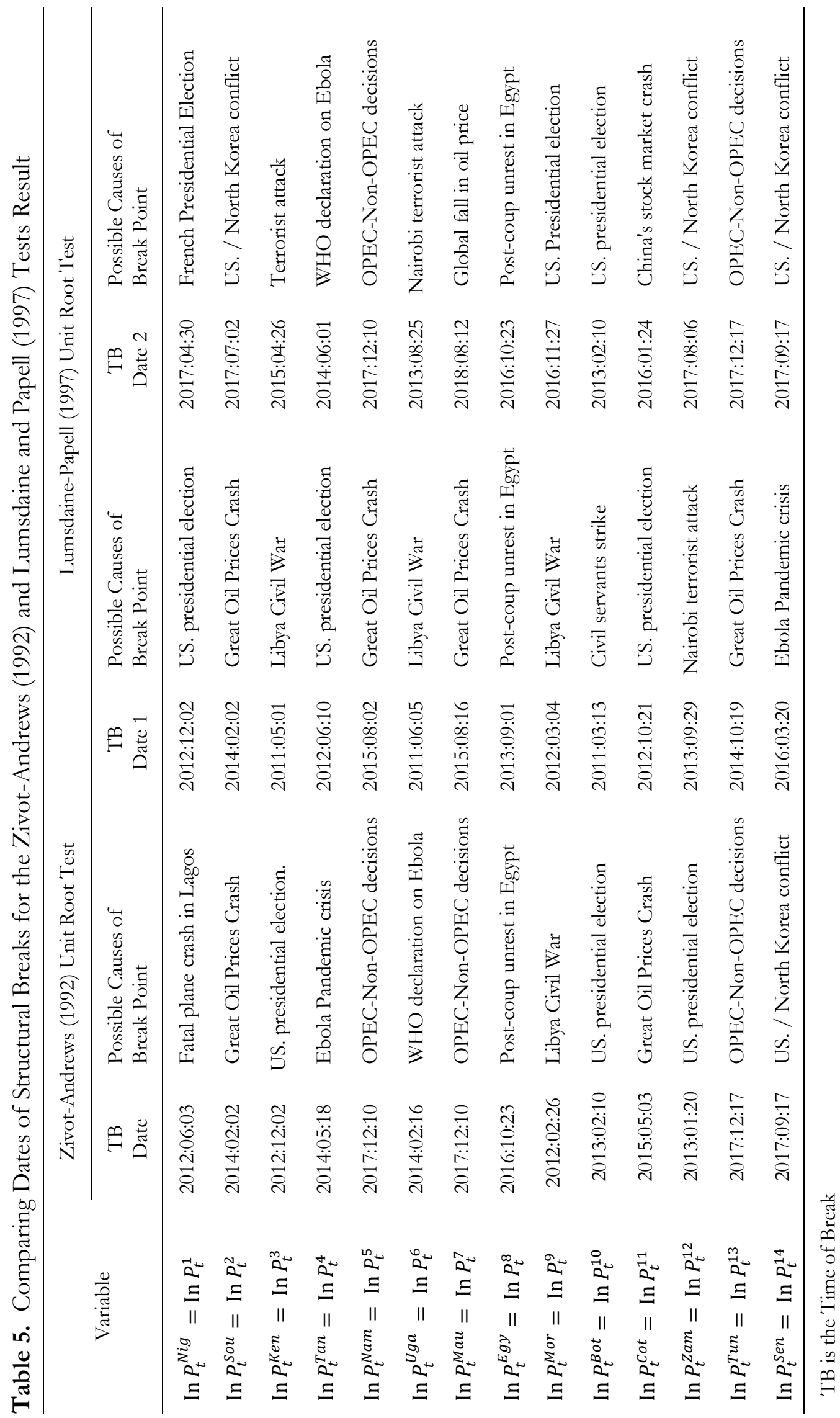




\section{Conclusion}

In this study, we test the unit root hypotheses for some African stock market indices in the presence of structural break. Since the Augmented Dickey-Fuller test is known to perform poorly in the presence of structural breaks, we employed the Ben-David et al. (2003) and Zivot and Andrews (1992) unit root tests which allow for one and two structural breaks respectively. The presence of unit root in analysis can cause spurious regressions with misleading statistical evidence. Hence, we examined whether African stock prices contain unit roots or mean reverting in the presence of structural breaks. We apply the weekly data for the period 31st May 2009 to $19^{\text {th }}$ April 2020. The $\mathrm{ADF}$ and PP unit roots test results only show the Botswana indices as mean reverting among all the fourteen countries examined. The result showed otherwise with the application of other unit root tests which allows for a break. This confirms Perron (1989) seminal paper that the ADF unit root test is unreliable in the presence of breaks. Apart from Senegal and Botswana which exhibit mean-reversion properties in its equity prices, an indication for the absence of unit root, we find strong evidence of unit root with structural breaks in all other African stock markets examined. This also shows that almost all African stock markets are weak form efficient. The implication for this is that African stock market investors can only outperform the market in the long run if they are ready to take an inordinate amount of risk. This is because investors cannot rely on past information and behavior to predict the market's situation or develop their trading strategy. Our study various break points (dates) closely coincide with the period of some global and regional events, both in Africa and the world in general.

\section{References}

Abakah, E. J. A., Alagidede, P., Mensah, Lord, \& Ohene-Asare, K. (2018). Non-linear approach to random walk test in selected African countries. International Journal of Managerial Finance, 14(3), 362-376. https://doi.org/10.1108/IJMF-10-2017-0235

Anoruo, E., \& Gil-Alana, L. A. (2011). Mean reversion and long memory in African stock market prices. Journal of Economics and Finance, 35(3), 296-308. https://doi.org/10.1007/s12197010-9124-0

Ben-David, D., Lumsdaine, R. L., \& Papell, D. H. (2003). Unit roots, postwar slowdowns and long-run growth: Evidence from two structural breaks. Empirical Economics, 28(2), 303319. https://doi.org/10.1007/s001810200132

Chaudhuri, K., \& Wu, Y. (2003). Random walk versus breaking trend in stock prices: Evidence from emerging markets. Journal of Banking \& Finance, 27(4), 575-592. https://doi.org/10.1016/S0378-4266(01)00252-7

Chia, R., Jiun, C., \& Xin, P. W. (2019). Does mean reversion occur in selected African stock markets? In Proceedings of the International Conference on Economics (pp. 60-66).

Chow, K. V., \& Denning, K. C. (1993). A simple multiple variance ratio test. Journal of Econometrics, 58(3), 385-401. https://doi.org/10.1016/0304-4076(93)90051-6

Dewandaru, G., Masih, R., \& Masih, A. M. M. (2016). Contagion and interdependence across Asia-Pacific equity markets: An analysis based on multi-horizon discrete and continuous wavelet transformations. International Review of Economics \& Finance, 43, 363-377. https://doi.org/10.1016/j.iref.2016.01.002

Dickey, D. A., \& Fuller, W. A. (1979). Distribution of the estimators for autoregressive time series with a unit root. Journal of the American Statistical Association, 74(366), 76-66. https://doi.org/10.2307/2286348 
Elliott, G., Rothenberg, T. J., \& Stock, J. H. (1996). Efficient tests for an autoregressive unit root. Econometrica, 64(4), 813-836. https://doi.org/10.2307/2171846

Enders, W., \& Lee, J. (2012). A unit root test using a fourier series to approximate smooth breaks*. Oxford Bulletin of Economics and Statistics, 74(4), 574-599. https://doi.org/10.1111/j.1468-0084.2011.00662.x

Fama, E. F., \& French, K. R. (1988). Permanent and temporary components of stock prices. Journal of Political Economy, 96(2), 246-273. https://doi.org/10.1086/261535

Glynn, J., \& Perera, N. (2007). Unit root tests and structural breaks: A survey with applications. Journal of Quantitative Methods for Economics and Business Administration, 3(1), 63-79.

Graham, M., Peltomäki, J., \& Sturludóttir, H. (2015). Do capital controls affect stock market efficiency? Lessons from Iceland. International Review of Financial Analysis, 41, 82-88. https://doi.org/10.1016/j.irfa.2015.05.009

Gyamfi, E. N., Kyei, K. A., \& Gill, R. (2016). Stationarity of African stock markets under an ESTAR framework. EuroEconomica, 2(35), 93-101.

Hayashi, N. (2005). Structural changes and unit roots in Japan's macroeconomic time series: Is real business cycle theory supported? Japan and the World Economy, 17(2), 239-259. https://doi.org/10.1016/j.japwor.2003.12.006

Hiremath, G. S., \& Narayan, S. (2016). Testing the adaptive market hypothesis and its determinants for the Indian stock markets. Finance Research Letters, 19, 173-180. https://doi.org/10.1016/j.frl.2016.07.009

Kwiatkowski, D., Phillips, P. C., Schmidt, P., \& Shin, Y. (1992). Testing the null hypothesis of stationarity against the alternative of a unit root: How sure are we that economic time series have a unit root? Journal of Econometrics, 54(1-3), 159-178. https://doi.org/10.1016/0304-4076(92)90104-Y

Lawal, A., Somoye, R., \& Babajide, A. (2017). Are African stock markets efficient? Evidence from wavelet unit root test for random walk. Economics Bulletin, 37(4), 2665-2679.

Lee, J., \& Strazicich, M. (2003). Minimum lagrange multiplier unit root test with two structural breaks. The Review of Economics and Statistics, 85(4), 1082-1089.

Lee, J., \& Strazicich, M. (2013). Minimum LM unit root test with one structural break. Economics Bulletin, 33(4), 2483-2492.

Ling, T. Y., Nor, A. H. S. M., Saud, N. A., \& Ahmad, Z. (2013). Testing for unit roots and structural breaks: Evidence from selected ASEAN macroeconomic time series. International Journal of Trade, Economics and Finance, 4(4), 230-237. https://doi.org/10.7763/ijtef.2013.v4.292

Magnusson, M., \& Wydick, B. (2002). How efficient are Africa's emerging stock markets? The Journal of Development Studies, 38(4), 141-156. https://doi.org/10.1080/00220380412331322441

Moin, S. (2007). New frontier markets tempt investors. African Review of Business and Technology, 1(1), $1-7$.

Morris, Q., Van Vuuren, G., \& Styger, P. (2009). Further evidence of long memory in the South African stock market. South African Journal of Economics, 77(1), 81-101.

https://doi.org/10.1111/j.1813-6982.2009.01203.x 
Narayan, P. K., \& Popp, S. (2010). A new unit root test with two structural breaks in level and slope at unknown time. Journal of Applied Statistics, 37(9), 1425-1438. https://doi.org/10.1080/02664760903039883

Narayan, P., Liu, R., \& Westerlund, J. (2016). A GARCH model for testing market efficiency. Journal of International Financial Markets, Institutions and Money, 41(C), 121-138. https://doi.org/10.1016/j.intfin.2015.12.008

Nelson, C. R., \& Plosser, C. I. (1982). Trends and random walks in macroeconomic time series. Journal of Monterey Economics, 10, 139-162.

Ng, S., \& Perron, P. (1995). Unit root tests in ARMA models with data-dependent methods for the selection of the truncation lag. Journal of the American Statistical Association, 90(429), 268-281. https://doi.org/10.1080/01621459.1995.10476510

$\mathrm{Ng}$, S., \& Perron, P. (2001). LAG length selection and the construction of unit root tests with good size and power. Econometrica, 69(6), 1519-1554. https://doi.org/10.1111/14680262.00256

Perron, P. (1989). The great crash, the oil price shock, and the unit root hypothesis. Econometrica, 57(6), 1361-1401. https://doi.org/10.2307/1913712

Phillips, P. C. B., \& Perron, P. (1988). Testing for a unit root in time series regression. Biometrika, 75(2), 335-346. https://doi.org/10.2307/2336182

Poterba, J. M., \& Summers, L. H. (1988). Mean reversion in stock prices: Evidence and implications. Journal of Financial Economics, 22(1), 27-59. https://doi.org/10.1016/0304405X(88)90021-9

Senbet, L., \& Otchere, I. (2008). Beyond banking: Developing markets; African stock market Organized by the (African Finance for the 21st Century High-Level Seminar No. 21). Tunisia.

Sensoy, A., \& Tabak, B. M. (2015). Time-varying long term memory in the European Union stock markets. Physica A: Statistical Mechanics and Its Applications, 436, 147-158. https://doi.org/10.1016/j.physa.2015.05.034

Smith, G., Jefferis, K., \& Ryoo, H.-J. (2002). African stock markets: Multiple variance ratio tests of random walks. Applied Financial Economics, 12(7), 475-484. https://doi.org/10.1080/09603100010009957

Suresh, K. G., \& Shylajan, C. S. (2015). Structural Breaks and Unit Roots in Indian Macroeconomic Variables. Theoretical and Applied Economics, 4(605), 145-150.

Tiwari, A. K., \& Kyophilavong, P. (2014). New evidence from the random walk hypothesis for BRICS stock indices: a wavelet unit root test approach. Economic Modelling, 43, 38-41. https://doi.org/10.1016/j.econmod.2014.07.005

Trabelsi Mnif, A. (2017). Political uncertainty and behavior of Tunisian stock market cycles: Structural unobserved components time series models. Research in International Business and Finance, 39(A), 206-214. https://doi.org/10.1016/j.ribaf.2016.07.029

Tuyon, J., \& Ahmad, Z. (2016). Behavioural finance perspectives on Malaysian stock market efficiency. Borsa Istanbul Review, 16(1), 43-61. https://doi.org/10.1016/j.bir.2016.01.001

Urquhart, A., \& McGroarty, F. (2016). Are stock markets really efficient? Evidence of the adaptive market hypothesis. International Review of Financial Analysis, 47, 39-49. https://doi.org/10.1016/j.irfa.2016.06.011 
Yamamoto, T. (1996). A simple approach to the statistical inference in linear time series models which may have some unit roots. Hitotsubashi Journal of Economics, 37(2), 87-100.

Zivot, E., \& Andrews, D. W. K. (1992). Further evidence on the great crash, the oil-price shock, and the unit-root hypothesis. Journal of Business \& Economic Statistics, 10(3), 251-270. https://doi.org/10.2307/1391541 